\title{
High-Pressure Carbon Dioxide Used for Pasteurization in Food Industry
}

\author{
Tonghuan $\mathrm{Yu}^{1}$ (D) $\cdot$ Liyuan $\mathrm{Niu}^{2} \cdot$ Hitoshi Iwahashi ${ }^{1}$ (D) \\ Received: 19 February 2020 / Accepted: 2 July 2020 / Published online: 21 July 2020 \\ (C) Springer Science+Business Media, LLC, part of Springer Nature 2020
}

\begin{abstract}
The demand for safe, high-quality food has greatly increased, in recent times. As traditional thermal pasteurization can significantly impact the nutritional value and the color of fresh food, an increasing number of nonthermal pasteurization technologies have attracted attention. The bactericidal effect of high-pressure carbon dioxide has been known for many years, and its effect on food-related enzymes has been studied. This novel technology has many merits, owing to its use of relatively low pressures and temperatures, which make it a potentially valuable future method for nonthermal pasteurization. For example, the inactivation of polyphenol oxidase can be achieved with relatively low temperature and pressure, and this can contribute to food quality and better preserve nutrients, such as vitamin C. However, this novel technology has yet to be developed on an industrial scale due to insufficient test data. In order to support the further development of this application, on an industrial scale, we have reviewed the existing information on high-pressure carbon dioxide pasteurization technology. We include its bactericidal effects and its influence on food quality. We also pave the way for future studies, by highlighting key areas.
\end{abstract}

Keywords Nonthermal pasteurization $\cdot$ High-pressure carbon dioxide $\cdot$ Food industry $\cdot$ Bactericidal effect $\cdot$ Food quality

\section{Introduction}

The consumer demand for better food safety, quality, and nutritive value has been increasing. However, traditional thermal pasteurization technologies can destroy the content of food. Furthermore, the color of food is always altered by traditional thermal pasteurization methods which may reduce the value of food products [1].

Hence, in recent years, an increasing number of nonthermal pasteurization technologies have been studied by leading scientists in the fields; these technologies entail the use of high hydrostatic pressure, ultraviolet (UV) irradiation, ultrasound, high-pressure carbon dioxide (HPCD), high-pressure homogenization, and microfiltration.

Since Valley and Rettger, in 1927, discovered the bactericidal effect of pressurized $\mathrm{CO}_{2}$, an increasing number

Tonghuan Yu

yutonghuan63@163.com

1 Faculty of Applied Biological Sciences, Gifu University, 1-1 Yanagido, Gifu 501-1193, Japan

2 Henan Key Laboratory of Cold Chain Food Quality and Safety Control, Zhengzhou University of Light Industry, Zhengzhou 450001, People's Republic of China of scientists have conducted research on HPCD inactivation in microorganisms, as a novel nonthermal pasteurization technology for the food industry. In the year 2012, the number of published papers about HPCD inactivation on food increased notably (Fig. 1). Although HPCD pasteurization has yet to reach a large commercial scale, more people are realizing its potential as a technology for food pasteurization, following significant, positive results from research concerning its bactericidal effect [2]. HPCD is a novel nonthermal pasteurization technology that applies pressurized $\mathrm{CO}_{2}$ at $\geq 0.1 \mathrm{MPa}$ ( 1 bar $)$, at a relatively low temperature (lower than thermal pasteurization). Carbon dioxide presents different phases at different temperatures and pressures (Fig. 2). Above critical conditions $\left(7.38 \mathrm{MPa}, 31.1{ }^{\circ} \mathrm{C}\right.$ or 73.8 bar, $\left.304.25 \mathrm{~K}\right), \mathrm{CO}_{2}$ always exists as a supercritical fluid, which has properties of gas and liquid [3]. Until now, HPCD inactivation studies have generally been conducted at temperatures ranging from room temperature $\left(25{ }^{\circ} \mathrm{C}\right.$ or $\left.298.15 \mathrm{~K}\right)$ to $100{ }^{\circ} \mathrm{C}$ $(373.15 \mathrm{~K})$ and pressures ranging from 0.1 to $50 \mathrm{MPa}$. Hence, for HPCD inactivation technology, carbon dioxide is generally found in the gas phase or as a supercritical fluid (Fig. 2).

In this review, we present a simple introduction to current pasteurization technologies, followed by a 
Fig. 1 The yearly published papers in PubMed about highpressure carbon dioxide on food
Yearly published papers in PubMed about HPCD on Food.

350

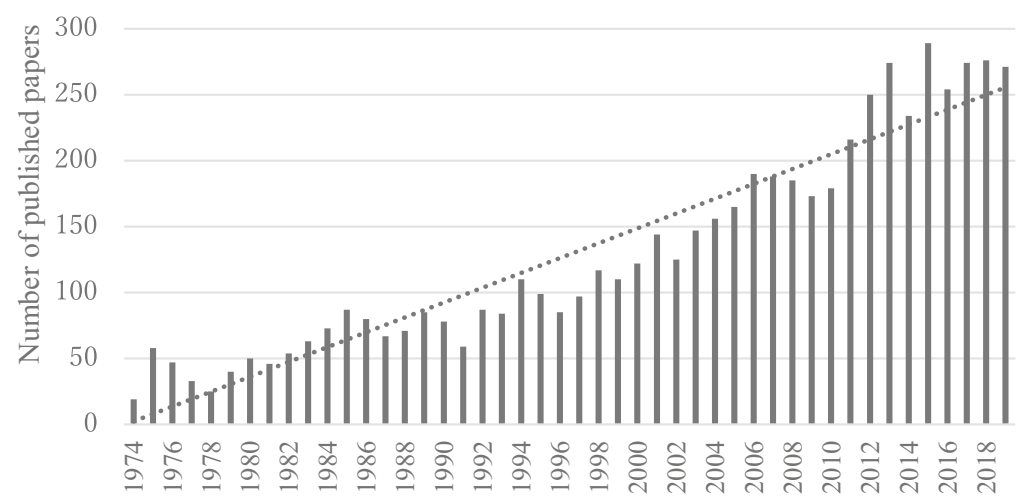

discussion of the applications of HPCD in the food industry, including the inactivation of bacteria, spores, and viruses. The lack of clarity and details regarding the mechanisms of HPCD inactivation of microorganisms is a major obstacle to its industrial application. Therefore, possible mechanisms of bactericidal activity are fully discussed in this review, including information from recent studies. The effects of HPCD on food quality and nutritive value are also introduced. Many studies have showed that HPCD could be a useful alternative pasteurization technique providing better nutrition and contributing to food quality by inactivating some enzymes. In this paper, we also discuss the issues of HPCD technology, faced by the food industry, and present some suggestions for future work. Our aim is to stimulate future interest in the application of HPCD nonthermal pasteurization technology in the food industry.

\section{The Introduction of Pasteurization Technologies in the Food Industry}

\section{High Hydrostatic Pressure}

High hydrostatic pressure (HHP) is currently the most used and developed industrial, nonthermal decontamination technology. Since HHP and HPCD both apply pressure, a great description of HHP is given here, compared with other technologies, such as thermal pasteurization, irradiation, ultrasound, and pulsed electric fields. Japan was the first country, in 1990, to start commercial food processing of fruit jams with HHP. After that, an increasing number of commercial applications of HHP were developed by the food industry [4]. Generally, pressures of 100 600 MPa are applied for commercial pasteurization by HHP. However, pressures in this range cannot satisfy the requirements of commercial steriliza-
Fig. 2 Schematic representation of carbon dioxide phase diagram

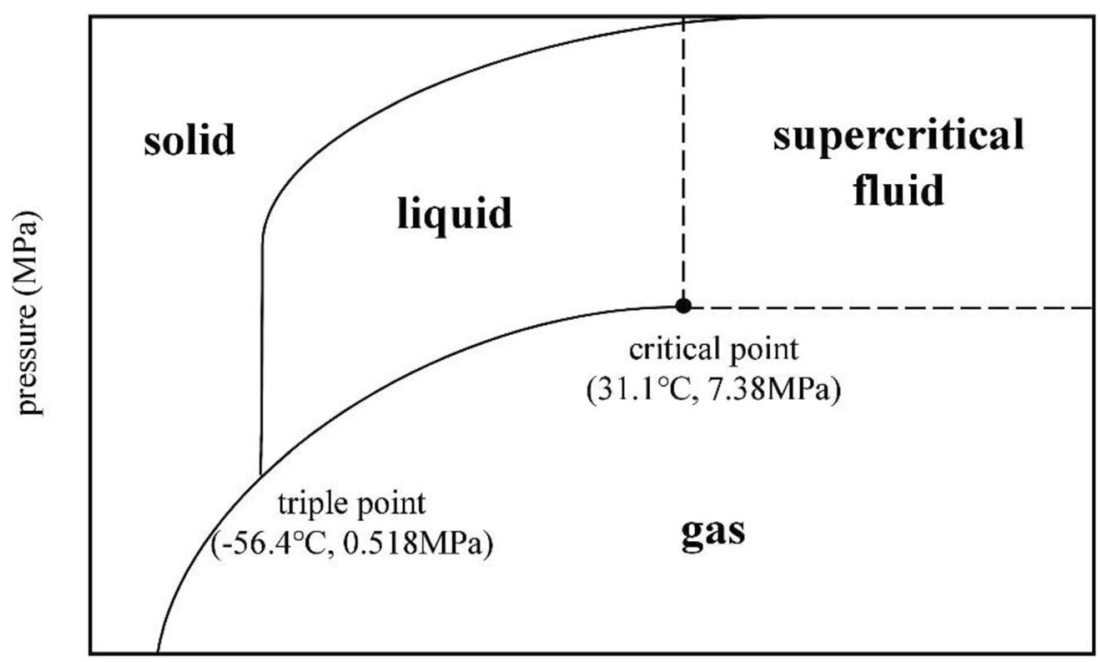

temperature $\left({ }^{\circ} \mathrm{C}\right)$ 
tion, since they are unable to destroy bacterial spores. The temperature should be moderately raised $\left(90 \sim 120^{\circ} \mathrm{C}\right)$ in combination with HHP, to achieve commercial sterilization $[5,6]$.

The mechanisms and factors of HHP pasteurization on microorganisms have been well discussed in some reports. The alteration of membranes is considered to be the main lethal mechanism [6,7], and damage to the nuclear membrane has been described as the lethal factor in yeast cells $[8,9]$.

The irreversible denaturation of proteins was also observed after HHP treatment. This would include the inactivation of enzymes that normally limit the storage period [6]. The same result was confirmed by Buzrul [10]. It has also been reported that this technology can maintain the stability of fatty acids, which play a significant role in the sensory characteristics of meat [11]. It should be noted that a higher fat content will decrease the efficiency of HHP in the inactivation of bacteria [12].

Packaged food is frequently submerged in water, in a tank, prior to HHP treatment. Generally, the temperature of is maintained at $\leq 30{ }^{\circ} \mathrm{C}$ even when the pressure increase to $600 \mathrm{MPa}$, which can preserve the food taste, color, flavor, nutrition, and extrinsic features as far as possible, compared with traditional thermal pasteurization $[6,13,14]$. Water is usually used as a pressure transmission medium. Hence, pressure can be transmitted to all points, to ensure uniform pasteurization without consideration of composition, shape, or size. However, when food is treated inside its packaging, it should have the ability to survive volume reductions of up to $15 \%$ [15].

Due to the high cost of investment, the price of HHP processed food is high. Therefore, the application of HHP is only an appealing choice for the market in higher-priced, healthier food products. HHP processed food is considered to contain more nutrition and provide more health benefits than food pasteurized by traditional methods $[4,16]$. This is also a good choice for extracting medicinal products with higher bioactivity and higher efficiency [17].

\section{Thermal Pasteurization}

The two best known thermal pasteurization methods are "low-temperature long time" and "high-temperature short time," which are widely applied to milk pasteurization. To maintain the chemical, physical, and sensory qualities of pasteurized milk, ultra-high-temperature processing (UHT) was developed. UHT processing generally uses a high temperature for a short time, such as $150{ }^{\circ} \mathrm{C}$ for $2 \mathrm{~s}$. However, thermal pasteurization methods have many disadvantages for food ingredients and always influence the color of the product, which may then influence the product value $[1,18]$.

\section{Irradiation}

In this section, two main irradiation technologies for pasteurization are introduced: pulsed light technology and microwave radiation, which are both examples of non-ionizing radiation.

Pulsed light technology uses inert gas flash lamps to generate short-duration, high-power pulses across a broad spectrum. The wavelength range is from 200 to $1000 \mathrm{~nm}$ [19]. It has been shown that pulsed light technology can effectively inactivate various microorganisms [20-22]. Pulsed UV light is the most commonly used method that can destroy the conjugated carbon $=$ carbon double bonds in proteins and nucleic acids, followed by structural changes in the DNA, leading to cell death [20]. This technology has an approved ability to enhance food nutrition, without other properties being changed, compared with traditional thermal pasteurization [23], including the reduction of allergens which can provide consumers with healthier food [24,25]. However, pulsed light technology is generally considered as more suitable for surface pasteurization, for example, for decontamination of packaging. This is because light can be both absorbed and scattered by food, leading to lower decreased decontamination efficiency inside the food [26].

Microwave radiation is another radiation, with wavelengths from 1 to $1000 \mathrm{~mm}$ and frequencies from 300 to $300,000 \mathrm{MHz}$. The translational motion of molecules, vibration of the lattice consisting of atoms or ions, and the elevation of free electron energy in metals can all be induced by the electric and magnetic field interactions of microwaves. Microwave energy is absorbed by materials and converted to heat, which leads to microbial and enzyme inactivation [27, 28]. Microwave radiation has been widely used in the industrial food pasteurization process, to provide higher quality products by inactivating key pathogens, enzymes, and bacteria. Microwave power, resultant temperature, and treatment time can all influence the inactivation efficiency for bacteria [29]. However, because the heating process is volume-dependent, it is difficult to pasteurize materials in bulk, using microwaves.

\section{Pulsed Electric Fields}

Pulsed, high-voltage electric fields are mainly applied to the pasteurization of liquid food. Consequently, electropermeabilization of microorganisms can be induced, due to the influence of the electric field on the charged molecules in their membranes. The formation of pores in membranes is followed by cell death [30]. In addition, pulsed electric fields can inactive some enzymes by disordering their secondary or tertiary structures, leading to a conformational change [31]. Pulsed electric fields can effectively inactivate microorganisms, and some enzymes, providing safe and stable food, and can also maintain or enhance the nutritional value. For 
example, in wines treated with pulsed electric fields during the storage stage, a higher retention of phenolics and less degradation of volatiles has been observed [32]. The antioxidant activity of pine nut peptides can be improved by pulsed electric field treatment [33]. A higher concentration of carotenoids in fruit juice-skim milk and fruit juice-whole milk beverages was also observed [34]. The influence of pulsed electric fields on food nutrition and physicochemical properties has been well discussed by Gabric et al. [35].

\section{Ultrasound}

Ultrasound is a nonthermal pasteurization method that applies ultrasonic waves to rapidly initiate the formation of a large number of small bubbles, in liquids, which subsequently collapse, triggering disruption of cell membranes and damage to DNA [36]. The bactericidal effects of ultrasound have been identified in many microorganisms, such as Saccharomyces cerevisiae and Escherichia coli [37, 38]. Ultrasound pasteurization technology has great advantages for food processing because of its ability to preserve food quality, compared with traditional thermal pasteurization [39]. However, it requires a relatively long exposure, which can also impair food quality [40].

\section{High-Pressure Carbon Dioxide}

High-pressure carbon dioxide (HPCD) is a type of nonthermal pasteurization that applies pressurized $\mathrm{CO}_{2}$, at between $0.1 \mathrm{MPa}(1 \mathrm{bar})$ and $50 \mathrm{MPa}$ (500 bar). Compared with HHP pasteurization technology, HPCD uses less sophisticated equipment, since most microbes can be inactivated at under $50 \mathrm{MPa}$. HPCD possesses great potential as a novel, nonthermal pasteurization technology, and the bactericidal effects on various microorganisms and the influence of HPCD on nutritional compounds are the main subjects of this review.

Apart from the aforementioned pasteurization technologies, there are other nonthermal methods that have been studied by scientists. High-pressure homogenization, ultrafiltration, and microfiltration are the most commonly used membrane filtration techniques for fruit juice processing, and there are chemical methods, such as the use of natural antimicrobials [41-43].

\section{Factors Influencing the Inactivation Effect of HPCD}

The bactericidal effect of compressed $\mathrm{CO}_{2}$ has been known for nearly a hundred years [44]. It has been shown that the efficiency of HPCD in microorganism inactivation is related to many factors. Since many of these factors influence pasteurization efficiency, to varying degrees, a discussion of
HPCD inactivation factors should be presented here. We also expect this to provide useful guidance for industrial operation.

\section{Microorganism Species}

The bactericidal effects of HPCD on various bacteria have been well studied by scientists (Table 1). Different bacteria present different responses to HPCD treatment. It was observed that aerobic psychrophilic microorganisms are much more sensitive to HPCD than aerobic mesophilic microorganisms [50]. Furthermore, L. monocytogenes is much more sensitive than E. coli to HPCD treatment [52].

However, no pattern of bactericidal effect was found between gram-positive bacteria, gram-negative bacteria, or fungi, as far as current research goes. This suggests that the bactericidal effects of HPCD have no significant connection with the cell wall. Nevertheless, in the interest of scientific understanding, more research needs to be conducted to clarify the bactericidal effects of HPCD on grampositive and gram-negative bacteria, and on fungi, by varying and controlling the treatment conditions (temperature, pressure, time, and medium).

Although bacterial vegetative cells can be easily inactivated by HPCD, their spore forms are more difficult to inactivate by HPCD, in the same conditions of pressure, time, and temperature. For example, a relatively high temperature $\left(\sim 85^{\circ} \mathrm{C}\right)$ combined with $20 \mathrm{MPa}$ HPCD for $60 \mathrm{~min}$ is needed, to effectively inactivate spores of Bacillus subtilis [53]. However, more than $7 \mathrm{log}$ reduction of vegetative cells of the same species can be completed by treatment at $38{ }^{\circ} \mathrm{C}$ and 7.4 MPa for just $2.5 \mathrm{~min}$ [54]. The resistance of spores to HPCD has been ranked as follows: B. subtilis $>$ G. stearothermophilus $>B$. licheniformis $>B$. coagulans $>$ B. cereus [55].

It was also discovered that HPCD can inactivate bacteriophage T4 [2]. About a 4.0 log reduction for bacteriophage T4, $>3.0 \log$ reduction for bacteriophage MS2, > $3.3 \log$ reduction in bacteriophage $\mathrm{Q} \beta$, and just under a 3.0 log reduction in bacteriophage $\Phi X 174$ were all achieved at $0.7 \mathrm{MPa}$ for $25 \mathrm{~min}$ at $22{ }^{\circ} \mathrm{C}[56,57]$.

\section{Cell Concentration}

Bacterial samples with a higher concentration of cells show a lower efficiency of inactivation by compressed carbon dioxide than low-concentration samples [52]. When higher concentrations were treated with pressurized $\mathrm{CO}_{2}$, more cells clumped, which made it difficult for $\mathrm{CO}_{2}$ to penetrate the cell membranes, leading to a decreased bactericidal effect. Consequently, in real industrial applications, the initial concentration of cells should be taken into consideration for the pasteurization of biomass by HPCD. 


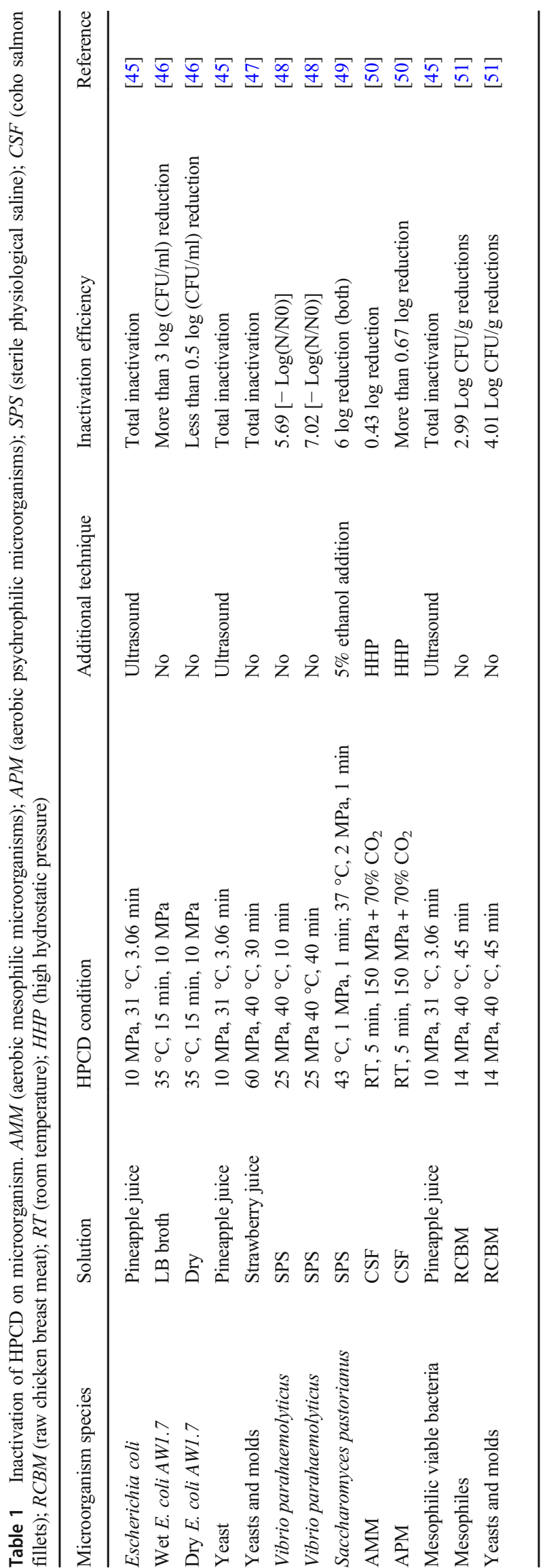

\section{pH and Water Content}

Some authors found that the efficiency of microbial inactivation by HPCD could be enhanced by decreasing the initial environmental $\mathrm{pH}$ [58]. However, regardless of the treatment pressure, the strain of microorganism, or exposure time, the $\mathrm{pH}$ of the endpoint after carbon dioxide treatment showed no significant difference [52]. The effect of $\mathrm{pH}$ was also investigated when the bacteriophage virus MS2 was treated with $\mathrm{HCl}$ (hydrochloric acid) under the same pressure as used for $\mathrm{HPCD}$, and $\mathrm{CO}_{2}$ treatment presented a higher sterilization effect than $\mathrm{HCl}$ treatment [57]. Hence, the $\mathrm{pH}$ decrease, which is induced by HPCD, is not the reason for microbial inactivation, but a lower initial environment $\mathrm{pH}$ can still improve the efficiency of inactivation.

Water has an important role in the inactivation efficiency of HPCD. A higher water content could enhance bactericidal efficiency. It has been suggested that wet cells are more sensitive to HPCD than dry cells [46]. For example, when wet E. coli in lysogeny broth was treated at $35^{\circ} \mathrm{C}$ at $10 \mathrm{MPa}$ with HPCD, for $15 \mathrm{~min}$, cell colonies were reduced by more than 3 $\log (\mathrm{CFU} / \mathrm{mL})$. However, when the dry E. coli was placed in the same conditions, cell colonies were reduced by $<0.5 \log$ $(\mathrm{CFU} / \mathrm{mL})$. Other researchers have also demonstrated that water content plays an essential role in the bactericidal effect of HPCD [59]. Generally, HPCD technology presents a better inactivation efficiency for liquid materials compared to solids.

\section{Physical State of Carbon Dioxide}

One interesting study showed that gaseous $\mathrm{CO}_{2}$ presents higher inactivation efficiency than supercritical $\mathrm{CO}_{2}$ or liquid $\mathrm{CO}_{2}$. In particular, when dry E. coli was treated with HPCD, more bactericidal activity can be accomplished with gaseous $\mathrm{CO}_{2}$, whereas dry E. coli are resistant to treatment by supercritical and liquid $\mathrm{CO}_{2}$ at the range of temperatures used [46]. However, a slightly higher temperature $\left(\sim 65^{\circ} \mathrm{C}\right)$ is still required for effective inactivation of dry E. coli.

\section{Treatment Time, Pressure, and Temperature}

Generally, $\mathrm{CO}_{2}$ treatment had an enhanced efficiency in cell destruction when the duration of exposure was increased. For example, $1.4 \log \mathrm{CFU} / \mathrm{g}$ reduction of $E$. coli can be achieved after 15 min of treatment, whereas a 45 -min treatment can induce up to $5 \log$ reduction [51]. However, longer treatment periods are not always worth the effort to increase inactivation. Fleury et al. [52] found that the efficiency increased with time, until the treatment period reached a certain point, and there was no further improvement at $50{ }^{\circ} \mathrm{C}$, even when the treatment was prolonged.

A higher inactivating effect of $\mathrm{CO}_{2}$ could be achieved by using higher pressure $[46,47]$. Higher pressure can enhance 
$\mathrm{CO}_{2}$ solubilization, facilitating its contact with and penetration into cells, which could explain the higher inactivation efficiency. Higher pressure can generate the same inactivation efficiency, at lower temperatures, as lower pressure can at a higher temperature [49]. Pressure has a positive effect on HPCD inactivation efficiency, but is not as important as temperature [52].

Among all the factors, temperature is considered to be the most important, to inactivate bacteria. However, temperature is not a factor to be regarded independently for bacterial inactivation. Similar pictures of cell cytoplasmic damage were observed at $38^{\circ} \mathrm{C}$ and $50{ }^{\circ} \mathrm{C}$, but only the higher temperature could achieve complete inactivation [52]. Despite this evidence, other studies suspect that pressure is the main lethal factor. According to them, a higher pressure can induce a decrease in $\mathrm{pH}$, which leads to microbial inactivation [47].

Garcia-Gonzalez et al. [60] described the schematic survival curves of bacteria with HPCD treatment. They explained that, during the HPCD process, the shapes of survival curves are related to the number of experimental data, the treatment time, and the pressure applied. Generally, sufficient experimental data tend to present a concave curve. However, fewer data are prone to show a log-linear curve (Fig. 3a, b), but when the pressure is increased, the shape of the curve is converted to concave (Fig. 3a).

\section{Combination with Other Technologies and Additives Effects}

Other factors also have some influence on the bactericidal effect of HPCD, such as agitation, the physicochemical environment, and some additives. Appropriate agitation can enhance the bactericidal efficiency of HPCD [61]. The microbial inactivation rate could be enhanced by certain additives, such as ethanol [49]. Especially for spores, additives can greatly increase the inactivation effect at relatively mild temperatures $\left(35-60{ }^{\circ} \mathrm{C}\right)$ [62-64]. When ultrasound is combined with HPCD, total inactivation can be reached in just 3 min, under $10 \mathrm{MPa}$, at $31{ }^{\circ} \mathrm{C}$ [45]. Another study, using HHP with HPCD, showed that the bactericidal effect is mainly due to the $\mathrm{CO}_{2}$ content, and not the pressure, since a pressure of $150 \mathrm{MPa}$ alone had no bactericidal effect, whereas $\mathrm{CO}_{2}$ alone could inactive the bacteria without increased pressure [50]. It has also been suggested that using a pressure $<200 \mathrm{MPa}$ for HHP is not effective in extending the storage period for salmon [65]. This suggests that pressure alone $($ at $<200 \mathrm{MPa})$ has a low efficiency of inactivation, without $\mathrm{CO}_{2}$.

\section{Inactivation Mechanism of HPCD}

\section{Mechanism of HPCD Inactivation in Vegetative Cells}

Many scientists have tried to explain the inactivation mechanism of HPCD. Although the details are still unknown, some theories have been more widely accepted, and will be discussed here with reference to published work, including some new findings. Additionally, we provide a novel direction for future studies, to clarify and improve the mechanisms of HPCD inactivation. A schematic diagram of mechanisms for the inactivation of vegetative microbial cells is shown in Fig. 4.

A detailed interpretation is given, in points (5) and (6), since $\mathrm{CO}_{2}$-induced membrane alternation is considered as the main reason for microbial inactivation.

(1) When bacterial cells are subjected to pressure, cell hydrophobicity will increase which can make the cells clump more easily. At higher cell concentrations, more cells clump, which leads to a decrease of inactivation rate by HPCD [52].

(2)Although cells are prone to clump under pressure, more severe shear force could be obtained from applying HPCD to separate cells. Therefore, higher pressure leads to a higher inactivation rate [47].

(3) Pressured $\mathrm{CO}_{2}$ can cause cell surface damage and disruption to intracellular organization.Under scanning and transmission electron microscopes (SEM and TEM), the alteration of microbial cell morphology can be visualized, after HPCD treatment. These alterations can be enhanced by longer treatment times [66, 67]. A large number of bulges were found on the extracellular surface of HPCD-treated cells, which indicates the leakage of cytoplasmic contents. However, morphological alteration is not necessarily the reason for cell death, because inactivated cells can still seem to be integral, under the TEM [52].
Fig. 3 Schematic representation of survival curve shapes (vegetative microbial cells) during HPCD inactivation (a socalled shoulder period was removed out of discussion in this paper). a Survival efficiency following time. b Survival efficiency following pressure
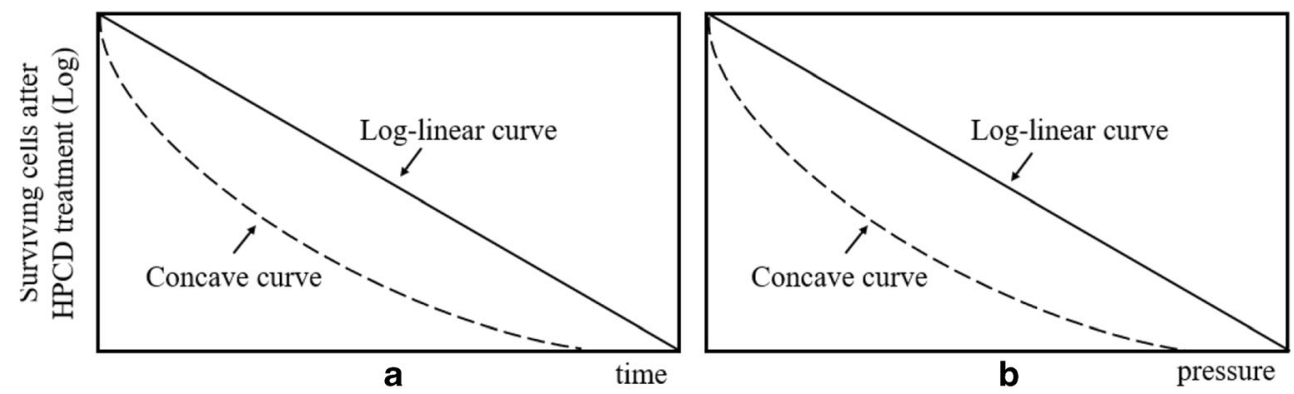


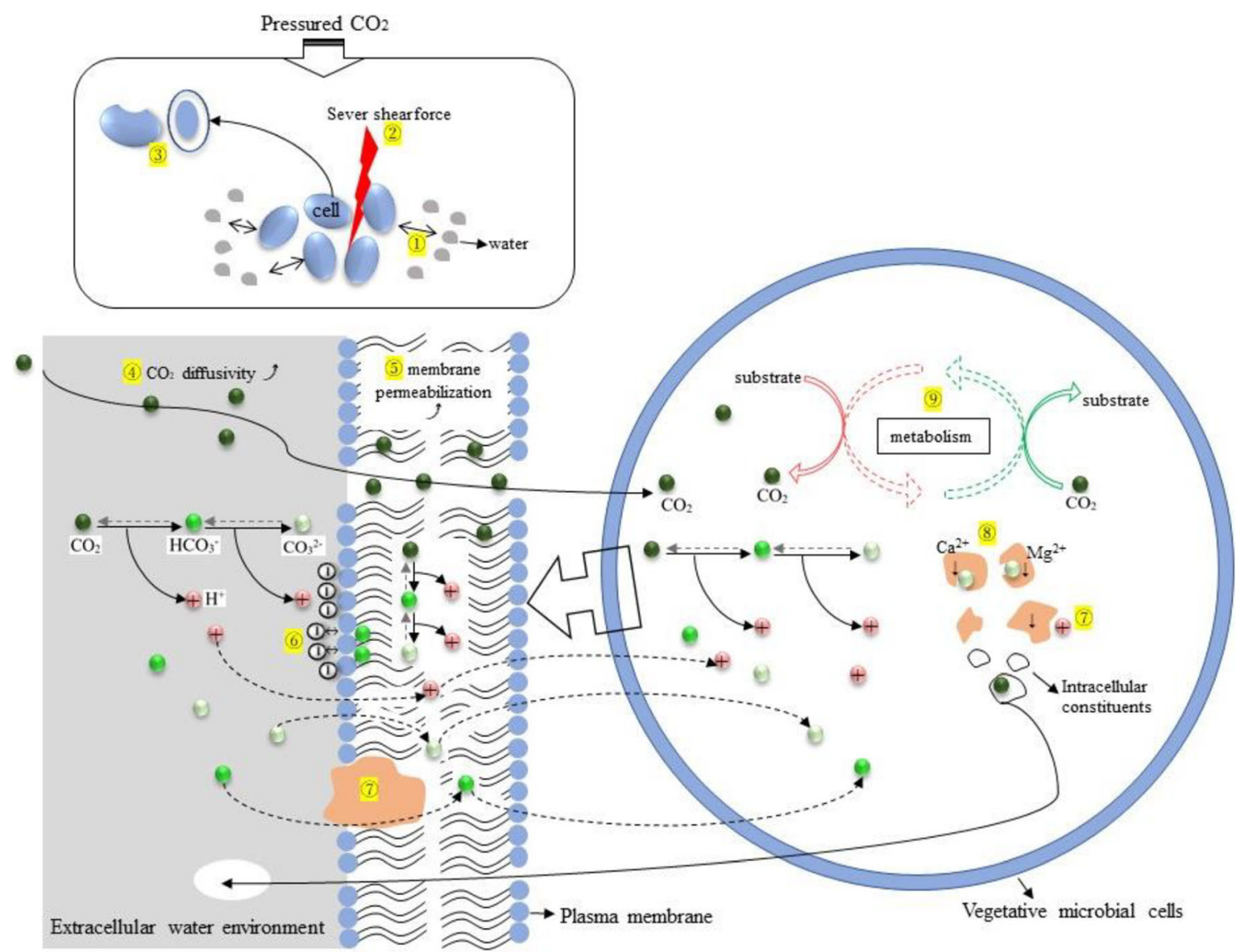

Fig. 4 Diagram of HPCD inactivation mechanisms on vegetative microbial cells

(4) $\mathrm{CO}_{2}$ diffusivity is enhanced at high pressure and extracellular $\mathrm{pH}$ is decreased. Dissolved $\mathrm{CO}_{2}$ can convert to $\mathrm{HCO}_{3}{ }^{-}$and $\mathrm{CO}_{3}{ }^{2-}$. Meanwhile, $\mathrm{H}^{+}$can be released from $\mathrm{H}_{2} \mathrm{O}$. In the aqueous extracellular environment, the $\mathrm{pH}$ will decrease due to release of $\mathrm{H}^{+}$, which can also increase membrane permeabilization, to allow more $\mathrm{CO}_{2}$ to enter the cytoplasm. This explains why the HPCD inactivation efficiency of dry strains was greatly decreased. However, regardless of the liquid matrix, the $\mathrm{pH}$ induced by the pressured $\mathrm{CO}_{2}$ will not decrease constantly with pressure and temperature.

(5) Membrane permeabilization and fluidity are enhanced.About $81 \%$ of cells were permeabilized and $18 \%$ of cells were partially permeabilized after $15 \mathrm{~min}$ of $\mathrm{CO}_{2}$ treatment under pressure $\left(12 \mathrm{MPa}\right.$ and $\left.35^{\circ} \mathrm{C}\right)$. Additionally, the ratio of phosphoglyceride to phosphatidylethanolamine decreased, which indicated that the stability of the E. coli membrane also decreased under approximately $12 \mathrm{MPa}$ of pressured $\mathrm{CO}_{2}$ treatment [68]. This study confirmed the increase in cell membrane permeability and the leakage of intracellular cytoplasmic solutes which may be essential for microbial growth. Another research showed that HPCD can lead to a decrease in total saturated fatty acid content and an increase in total unsaturated fatty acid content [48]. Subsequently, the stability and permeabilization of cell membranes are altered. Membrane damage in a large majority of cells was also observed in the work of Fleury et al. [52]. Kobayashi et al. [49] also found that higher temperatures can increase the phase transition of the membrane, which may disrupt cytoplasmic membrane permeabilization. Another study also found that the disruption of the endoplasmic reticulum, nuclear membrane, Golgi body, and nucleolus caused a reduction in yeast cell viability when Saccharomyces cerevisiae was treated by HPCD. The membranes of major organelles were damaged by HPCD treatment, rather than the cell membrane [69]. Their investigation proved that membrane damage is also a lethal cause for eukaryotes.

(6) Decreased $\mathrm{pH}$ and $\mathrm{HCO}_{3}{ }^{-}$(produced from $\mathrm{CO}_{2}$ ) in the membrane can destroy the membrane surface charge balance and alter membrane functions. The lower $\mathrm{pH}$ produced by pressured $\mathrm{CO}_{2}$ may decrease the activity of some membrane proteins, and become deleterious to their biological functions. $\mathrm{HCO}_{3}{ }^{-}$ions produced by pressured $\mathrm{CO}_{2}$ can change proteinlipid electrostatic interactions. For example, the topology of the inner membrane protein is believed to be influenced by the presence of negatively charged phospholipids [70], which may be changed by $\mathrm{HCO}_{3}{ }^{-}$ions. The localization of the charged amino acids in the membrane may also be influenced by $\mathrm{HCO}_{3}{ }^{-}$ions. It should be noted that the conformation and function of membrane proteins are related to the composition 
and distribution of membrane lipids [71]. Hence, alteration of membrane protein activity may influence the composition and distribution of membrane lipids. This explanation was corroborated by a study of lipid A, which plays an important role in cell survival and is distributed in the periplasmic space [48]. However, more studies are needed on how $\mathrm{HCO}_{3}{ }^{-}$ions and decreased $\mathrm{pH}$ might influence the functioning of membrane proteins.Furthermore, there are many DNA-specific attachment sites on cell membranes. These are required for DNA replication and for the process of cell segmentation [72]. As we have accepted that cell membranes can be altered significantly by HPCD, the possible alteration of DNA-specific attachment sites should be taken into consideration. This might provide more evidence for the mechanisms of the bactericidal effect of HPCD, and is another avenue for future research.

(7) Some proteins and enzymes may lose their activities, due to HPCD treatment. The activity of $\mathrm{Na}+\mathrm{K}+-\mathrm{ATPase}$, the main enzyme that maintains the balance of various substances inside and outside of cells, has been shown to be significantly decreased by HPCD, especially under higher pressure and longer treatment times [48]. Alkaline phosphatase, a periplasmic enzyme, can also be deactivated at lower temperatures with HPCD than with thermal treatment alone [49]. However, the intracellular $\mathrm{pH}$ change brought about by pressured $\mathrm{CO}_{2}$ is not a major contributor to lethality [46]. Decreased $\mathrm{pH}$ was considered as the reason for some protein deactivation. However, the latest research suggests that protein deactivation by HPCD is due to an "interfacial denaturation" mechanism. In their recent study, Monhemi and Dolatabadi [73] used a molecular dynamics simulation method to clarify the mechanism of HPCD inactivation of proteins and enzymes. They suggested that protein denaturation occurs at the $\mathrm{CO}_{2}$ /water interface in a HPCD pasteurization system. They found that hydrophobic regions in the protein cores were expanded upon arrival at the $\mathrm{CO}_{2}$ /water interface. First, when HPCD starts, proteins and enzymes become accessible to the $\mathrm{CO}_{2} /$ water interface. Pressurized micro-size $\mathrm{CO}_{2}$ bubbles and mixing in the processing vessel can both promote this movement. Second, hydrophobic protein regions start to unfold, from globular to flat and extending, in conformation. Third, tertiary protein structure undergoes change, followed by protein denaturation. This may also cause functional alterations in the membrane.

(8) Internal ribosomes and $\mathrm{CO}_{3}{ }^{2-}$ (produced from $\mathrm{CO}_{2}$ ) induce intracellular precipitation. Anions such as $\mathrm{CO}_{3}{ }^{2-}$ or $\mathrm{HCO}_{3}{ }^{-}$may precipitate intracellular inorganic electrolytes $\left(\mathrm{Ca}^{2+}\right)$, leading the cytoplasmic interior to lose its electrolytic balance. Subsequently, with increased permeability, these inorganic electrolytes and other constituents may transfer to the extracellular environment through the cell membrane. This has been confirmed by some studies. After HPCD treatment, an obvious increase was found in the types of protein in the supernatant, which indicated that the constituents of the cells were transferred to the extracellular space [48]. When intracellular constituents are removed, the structure of the biomembrane and the balance of the biological system may be altered, which could enhance the lethal effect of pressurized $\mathrm{CO}_{2}$.In addition, internal ribosomes and intracellular materials can be agglomerated or precipitated, followed by uneven distribution at the cell membrane [48]. Precipitation of intracellular ribosomes can, subsequently, cause confusion in gene expression.

(9) The metabolic pathways that require $\mathrm{CO}_{2}$ as a reagent can be stimulated. Those that can produce $\mathrm{CO}_{2}$ will be inhibited. Phosphatidylcholine synthesis increases with pressurized $\mathrm{CO}_{2}$ treatment. This can explain the enhanced stability of some cell membranes and cellular resistance to HPCD inactivation [67], as bacteria present enhanced adaptability to the adverse external environment. The metabolism of the urea cycle is also significantly enhanced, along with the induction of urea cycle-related genes [74]. These studies revealed that HPCD can influence cell metabolism.

\section{Mechanism of HPCD Inactivation of Spores}

Spores usually possess a high ability to resist physical and chemical treatment, due to their unique structure [75]. Spore structure includes an exosporium, a coat layer, outer membrane, cortex, germ cell wall, inner membrane, and core [76] (Fig. 5). The permeability barrier is composed of an exosporium, a coat layer, and a cortex that contributes to spore resistance against pressure or attack by chemicals and lytic enzymes [75].

Generally, spore inactivation by HPCD proceeds as follows. When heat is applied to spores, the enzymes in the spores may be activated, which may lead to cell modification. This provides an opportunity for $\mathrm{CO}_{2}$ to penetrate the cell, followed by damage to the cell structure and metabolic systems. Subsequently, the fluidity and permeability of the inner membrane are increased by the HPCD. The evidence shows that HPCD treatment can trigger the loss of core materials from spores, such as metal ions and dipicolinic acid (DPA) from the inner membrane [77, 78]. Due to an increase in the permeability of the inner membrane, the heat resistance of the spore is also reduced by HPCD treatment. It should be noted that germination is not the reason that heat resistance of spores is reduced, as HPCD-treated spores did not undergo typical germination due to the damage of germinant receptors. Then, spore outgrowth is blocked due to the absence of germination, which leads to spore death $[53,78]$.

\section{HPCD Inactivation on Food Enzymes}

HPCD can promote the inactivation of enzymes. Especially in some fruits, vegetables, and some related products, peroxidase 


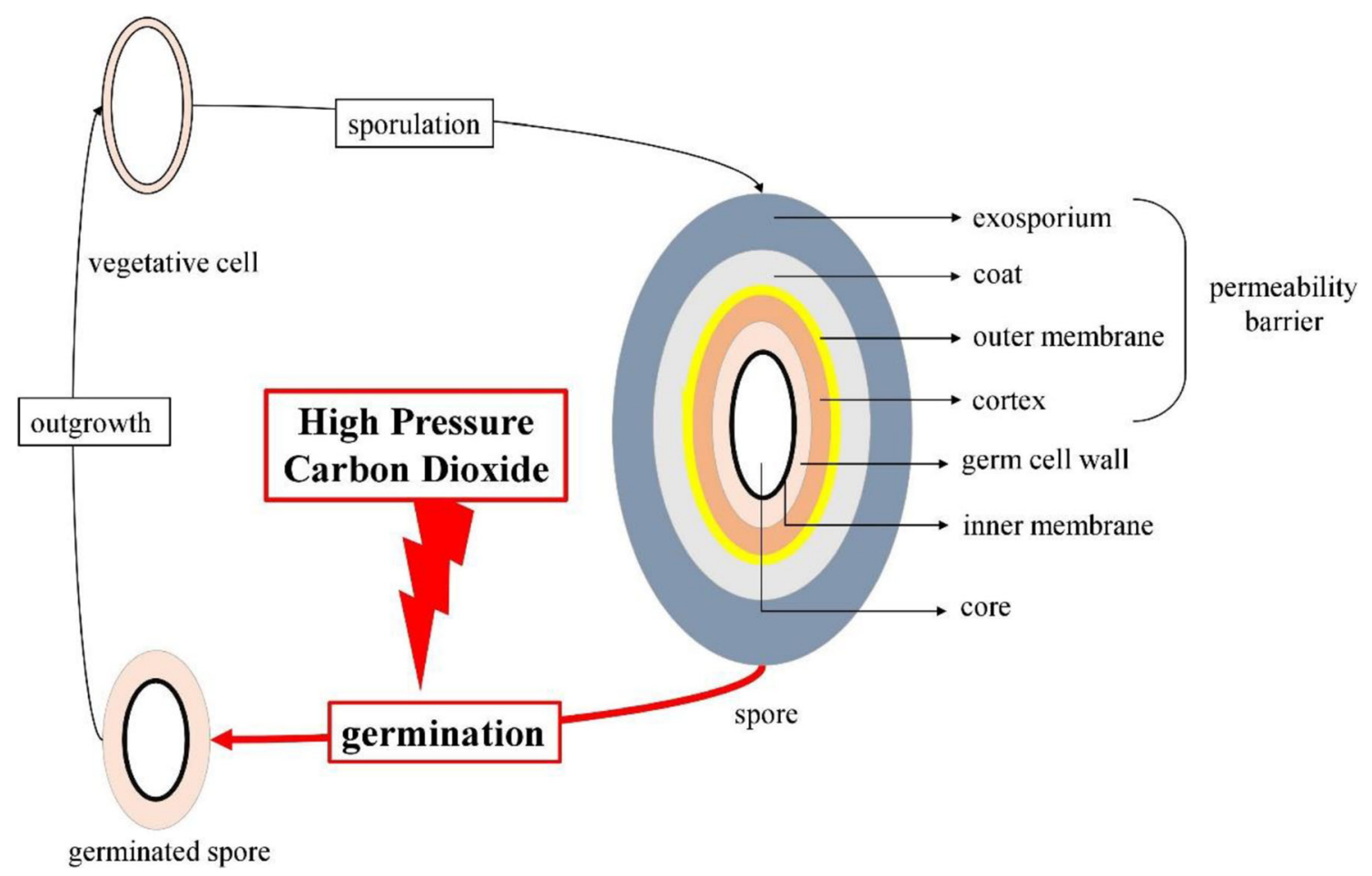

Fig. 5 Diagram of spore inactivation by HPCD

and polyphenol oxidase are the most important enzymes to negatively affect food quality by browning, the formation of off-flavors, and the loss of vitamins and pigments. The inactivation of peroxidase and polyphenol oxidase activity by HPCD is dependent on temperature, pressure, and time (Table 2). The remaining peroxidase activity was $61.39 \%$ after treatment with $\mathrm{CO}_{2}$ at $20 \mathrm{MPa}$ and $45^{\circ} \mathrm{C}$ for $20 \mathrm{~min}$, whereas, only $29.32 \%$ peroxidase activity was preserved when the temperature increased to $65^{\circ} \mathrm{C}$. Without HPCD, peroxidase activity remained at $94.56 \%$, even when the temperature was increased to $65^{\circ} \mathrm{C}$ [79]. When the $\mathrm{CO}_{2}$ pressure increased to $30 \mathrm{MPa}$ for $30 \mathrm{~min}, 83 \%$ of the peroxidase was effectively inactivated [47]. Compared with peroxidase, polyphenol oxidase is much more sensitive to HPCD treatment. HPCD conditions of $30 \mathrm{MPa}$ and $45^{\circ} \mathrm{C}$ for 30 min can totally inactivate polyphenol oxidase [47].

The $\mathrm{CO}_{2}$ concentration is more important than the pressure, for inactivating enzymes. When $70 \% \mathrm{CO}_{2}$ was applied without pressure, $51 \%$ of protease was inactivated. When $150 \mathrm{MPa}$ was applied, without $\mathrm{CO}_{2}$, the inactivation was only $20 \%$. The same results were obtained for collagenase activity. When $150 \mathrm{MPa}$ pressure was applied with $100 \% \mathrm{CO}_{2}$, the inactivation of collagenase did not increase compared with $0 \mathrm{MPa}$ pressure and $100 \% \mathrm{CO}_{2}$ treated collagenase (Table 2) [50]. Beside these examples, many other enzymes have been successfully inactivated by HPCD [80-86].

For a possible mechanism by which HPCD might inactivate enzymes, Benito-Román et al. [87] found, by fluorescence spectroscopy analysis, that HPCD can trigger significant changes in an enzyme's tertiary structure. Following this result, as previously mentioned, Monhemi and Dolatabadi [73] found that the tertiary structure of proteins and enzymes is significantly changed from globular to flat and extended conformations. The alteration of protein structure is considered to be the main cause of inactivation, and a more detailed description has been given in Section 4.1 (7)).

\section{The Influence of HPCD on Food Nutrition and Organoleptic Properties}

\section{Nutrition}

As a kind of novel nonthermal pasteurization technology, the purpose of HPCD is to maintain more nutrition after pasteurization processing. Therefore, the influence of HPCD on food nutrition needs to be discussed. The effects of HPCD on nutritional value are summarized in Table 3 according to recent researches.

It was presented that, after HPCD treatment, the residual $\mathrm{Ca}^{2+}$ in the orange juice can keep at more than $90 \%$. More $\mathrm{Ca}^{2+}$ loss cannot be caused by higher temperatures but can be caused by higher pressure and longer treatment time [88]. Same with residual $\mathrm{Ca}^{2+}$, HPCD also induces a slight decrease in protein and lactose content [89].

Marszalek et al. [47] found that HPCD can enhance the sugar content. However, when the lower pressure, lower 


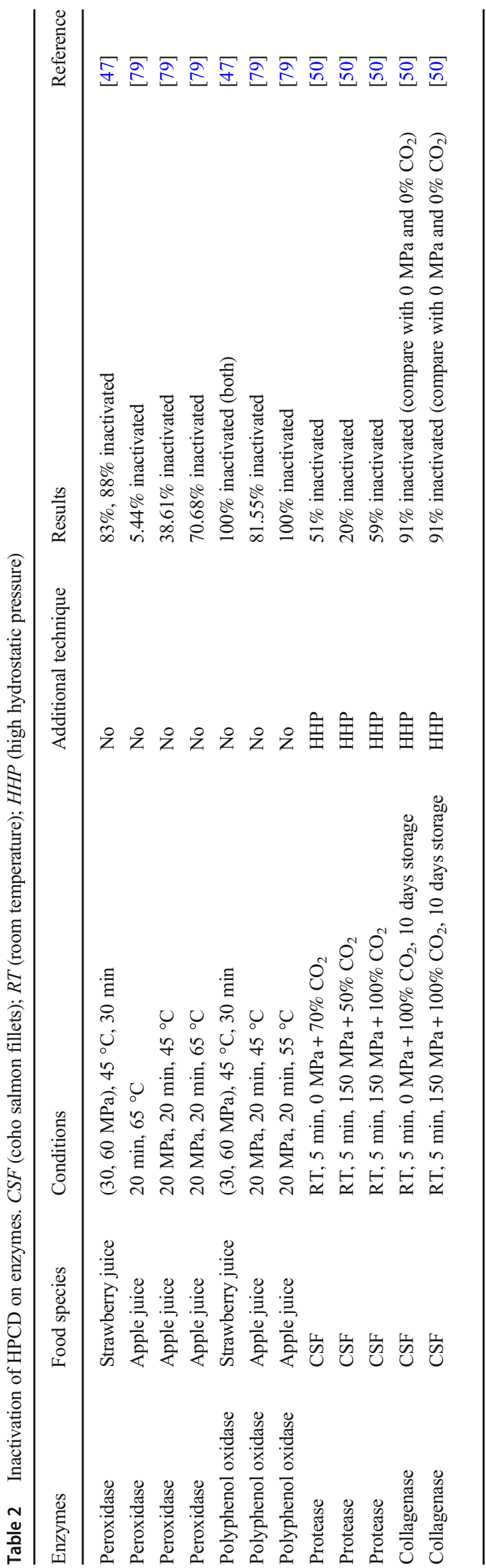

temperature, and less treatment time of HPCD was applied on inulin-enriched apple juice, HPCD treatment presented no big influence on sugar content [90].

For vitamin $\mathrm{C}$, pressure makes little difference to the preserved content because $60 \mathrm{MPa}$ can induce $33 \%$ loss, whereas $30 \mathrm{MPa}$ induced $30 \%$ loss. However, due to pressure utilization, the temperature can be decreased. Temperature has a greater influence on vitamin degradation than pressure. When the temperature decreased from 45 to $38{ }^{\circ} \mathrm{C}$, preserved vitamin $\mathrm{C}$ increased from 70 to $89 \%$. Furthermore, more vita$\min \mathrm{C}$ can be preserved at lower HPCD temperatures with the help of ultrasound [45, 47, 52].

HPCD treatment of below 20 MPa made no big effects on organic acids, a kind of very important nutritional compounds with antioxidant activity in many fruits [90]. The phenolic compounds, which also possess antioxidant activity, are also not influenced greatly by HPCD treatment $[79,90]$. However, Murtaza et al. [79] presented that higher temperatures can induce an even greater loss of phenolic content. Furthermore, when higher pressure and higher temperature $\left(60 \mathrm{MPa}, 55^{\circ} \mathrm{C}\right)$ were applied, about $30 \%$ polyphenols were degraded [91].

Anthocyanins are protected during HPCD, since there is no reduction after $30 \mathrm{MPa} 45^{\circ} \mathrm{C} \mathrm{HPCD}$ treatment for $30 \mathrm{~min}$. When the pressure is increased to $60 \mathrm{MPa}$, the anthocyanin content only decreased by $3 \%$ [47]. Betaxanthins which contribute to plants color and possess antioxidant ability were also invested under HPCD treatment. It was found that higher temperature and higher pressure can both increase betaxanthins degradation. Especially when the pressure was increased to $60 \mathrm{MPa}$ and the temperature increased to $55{ }^{\circ} \mathrm{C}$ for $30 \mathrm{~min}, 32.1 \%$ degradation of betaxanthins was detected [91]. Compared with betaxanthins, betacyanins seems much more sensitive to HPCD treatment.

In summary, despite betacyanins which are very sensitive to HPCD treatment, most nutritional compounds can only be degraded slightly by HPCD treatment. Therefore, HPCD can be used as a novel nonthermal pasteurization technology with low nutrition loss in the food industries. But according to these analyses that higher temperature and higher pressure can induce more nutrition degradation, lower pressure and lower temperature are recommended in the real industrial application.

\section{Organoleptic Properties}

To make the products more acceptable for consumers is also an essential task. Therefore, the organoleptic properties of HPCD-treated samples are discussed here. The influence of HPCD on food organoleptic properties has been summarized in Table 4. 


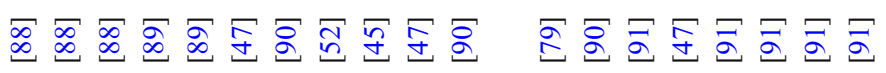

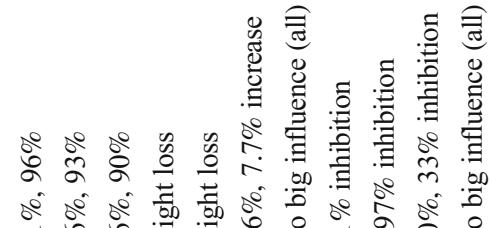

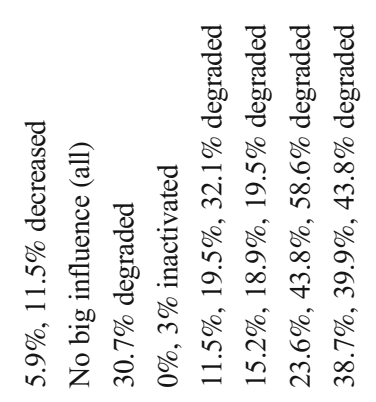

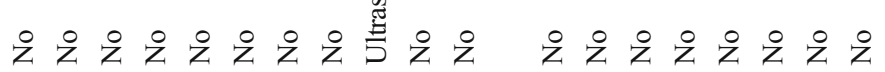

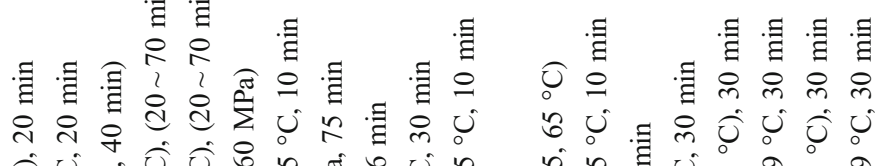

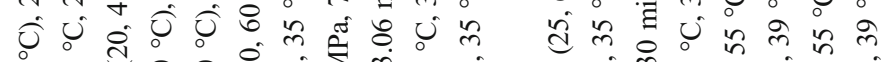

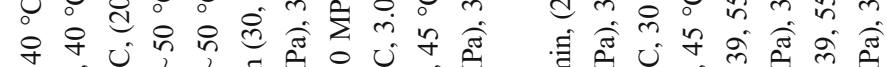
से०

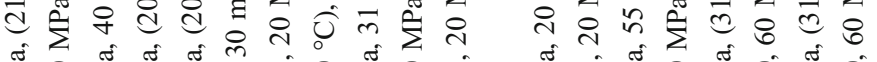

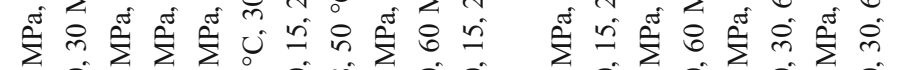

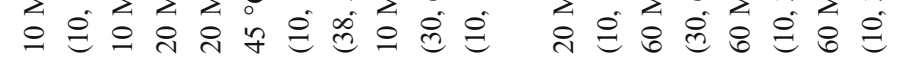
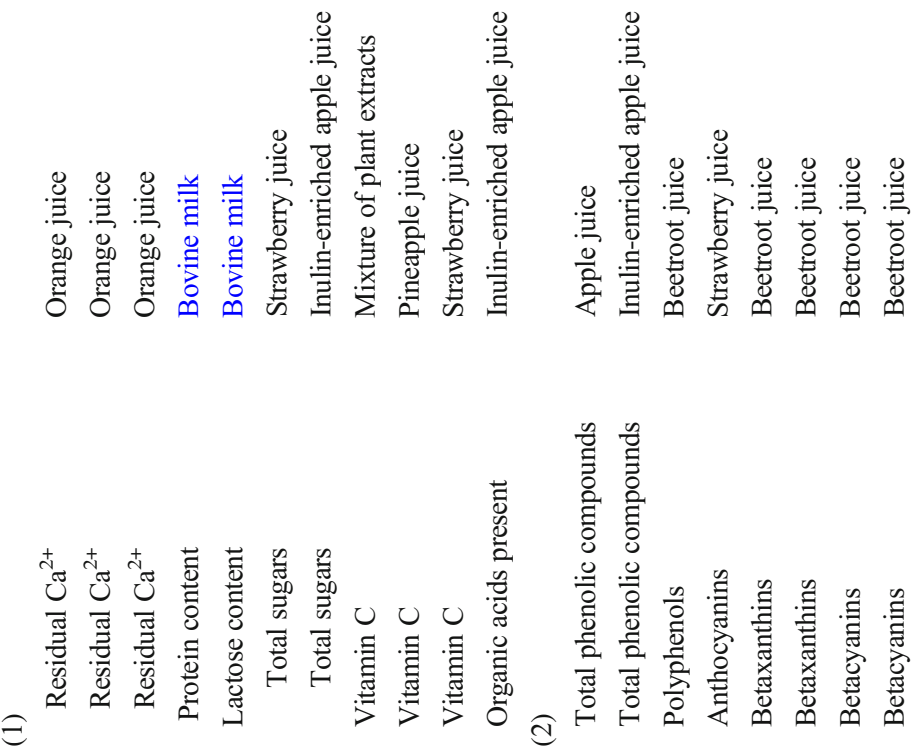


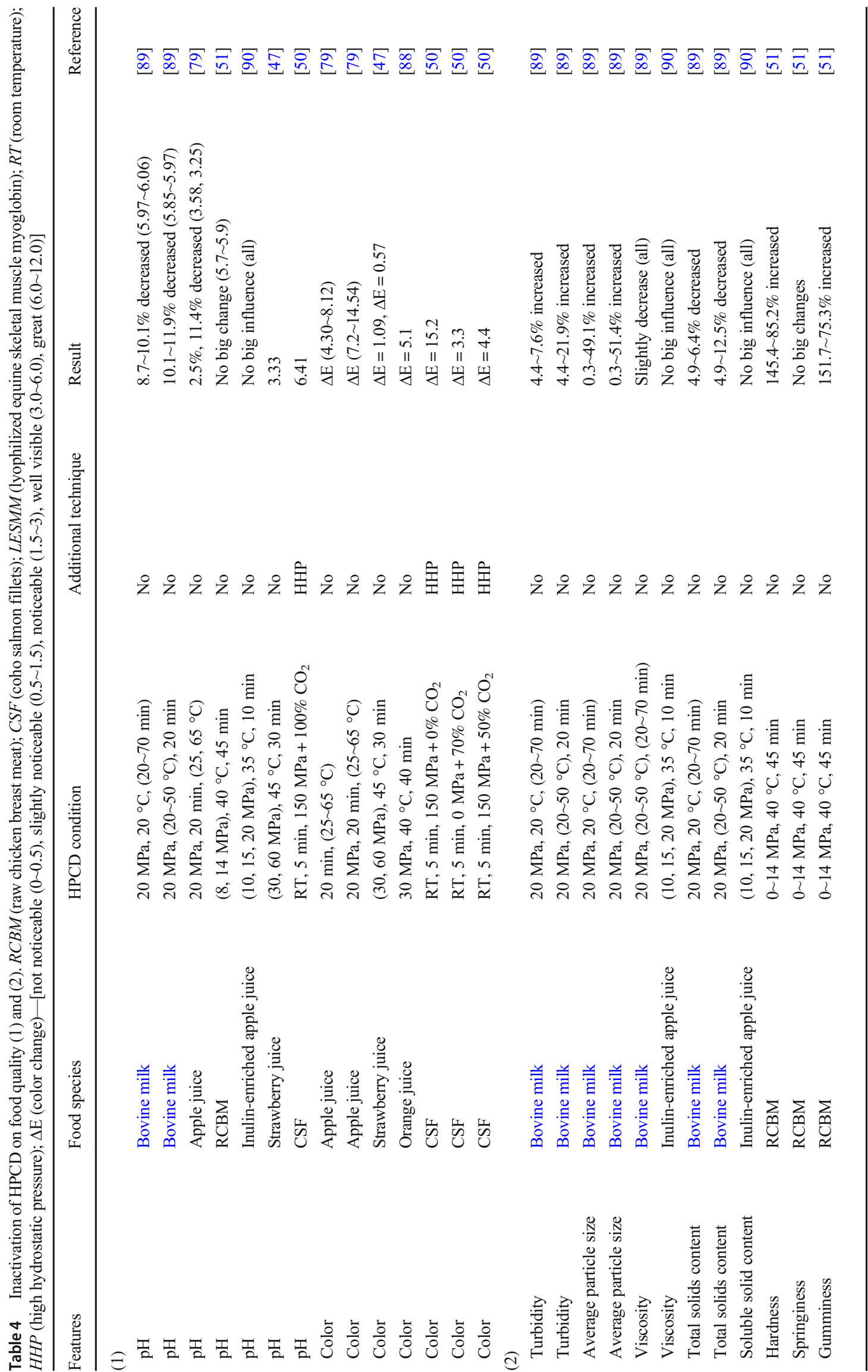


It was found that the HPCD technique can reduce the concentrations of volatile compounds in foods, and may influence their aroma $[92,93]$.

The $\mathrm{pH}$ and titratable acidity contribute to food sourness, total soluble solids, and sweetness (fructose, glucose, and sucrose). Because of the complex food matrix, HPCD has no significant influence on food $\mathrm{pH}$ (Table 4). However, the $\mathrm{pH}$ varies greatly between different foods. The $\mathrm{pH}$ of strawberry juice and apple juice is always between 3 and 4 regardless of the pressure, temperature, and treatment time. Whereas, the $\mathrm{pH}$ of HPCD-treated chicken breast meat stays at around 5.7 and the $\mathrm{pH}$ of coho salmon fillets is $6.41[47,50,51,79]$. However, HPCD can still induce a slight decrease in $\mathrm{pH}$ in apple juice. A higher pressure leads to a lower $\mathrm{pH}$ value, which indicates that higher pressure and temperature can trigger more $\mathrm{CO}_{2}$ being dissolved into water [79].

The alteration of food color by HPCD was investigated. The yellowness varied in different food sources and by different HPCD treatment conditions. The degree of browning is decreased in apple juice, carrot juice, and hami melon juice $[58,94,95]$. In recent studies, total color differences were used to analyze food color changes. A higher temperature caused a greater alteration in food color, and HPCD can increase the color alteration, at the same temperature, in apple juice. However, there were no significant changes in color when the strawberry juice was treated with HPCD. An obvious color change in orange juice was also observed under $30 \mathrm{MPa}, 40{ }^{\circ} \mathrm{C}$ for $40 \mathrm{~min}$ treatment. This suggests that the influence of HPCD on color varies between foods [47, 79, 88]. Another study demonstrated that, compared with $\mathrm{CO}_{2}$, pressure had a greater influence on food color (Table 4). PerezWon et al. [50] showed that, when pressure is applied without $\mathrm{CO}_{2}$, large changes in color could be observed. However, there was less change in the color with $\mathrm{CO}_{2}$ alone, without pressure treatment.

HPCD increases the cloudiness, average particle size, and viscosity of HPCD-treated juices, which can provide good juice quality for customers. For example, HPCD-treated orange juice presented an increased proportion of the smaller particles, which contributed to the juice cloud and stability, improving the juice quality. Furthermore, increased viscosity was observed in HPCD-treated peach juice [93, 96], but Silva et al. [90] observed that HPCD with relatively lower pressure and temperature made no big influence on the viscosity of inulin-enriched apple juice. The turbidity and average particle size of bovine milk can be increased by higher temperatures and longer treatment time, but HPCD can decrease the viscosity and total solids content of bovine milk, which is different from fruit juices [89].

For solid food, firmness of pear, hardness of carrot slices, and hardness of milled rice are all decreased after HPCD treatment [97-99]. When raw chicken breast meat was treated with HPCD, a decrease in gumminess and hardness was observed, with increasing pressure. In contrast, at higher pressure, springiness increased. However, it should be noted that the temperature can also increase gumminess and hardness, since a significant increase was found when the same temperature and treatment time was applied, without HPCD (Table 4) [51].

In summary, the many merits of HPCD treatment show that it is a good future choice as a nonthermal pasteurization technology, in the food industry. First, HPCD can effectively inactivate microorganisms and some food enzymes, which would negatively affect food quality and extrinsic features. Second, HPCD can provide products with a better appearance, which contributes to selling. Third, HPCD technology has a low requirement for equipment and cost, due to the application of relatively low temperatures and pressures.

However, our concern is that, except for some beverages with a lower initial $\mathrm{pH}, \mathrm{HPCD}$-treated products may influence the flavor, to some extent, because of decreased $\mathrm{pH}$. Therefore, in real industrial applications, the influence of HPCD on different products taste should be taken into consideration. It should also be noted that HPCD technology cannot be applied to soft foods and leafy vegetables because the applied pressure and $\mathrm{CO}_{2}$ may alter the food matrix and sensory characteristics, making food unacceptable for consumers.

\section{Future Prospects and Conclusions}

This review provides a simple introduction to existing pasteurization technologies in the food industry. The current state of knowledge, of HPCD pasteurization technology, has been explained. It has been confirmed that this process could be applied in the food industry as a novel, nonthermal pasteurization technology, since the bactericidal effect of HPCD has been widely tested on various microorganisms. Additionally, the influence of HPCD on food quality was considered. However, a lack of ample studies prevents HPCD technology from growing on an industrial scale. Although the inactivation of microorganisms by HPCD has been studied extensively, the detailed mechanisms are still unclear. Until now, studies have shown that the alteration of the cell membrane is the leading cause of bactericidal activity. Hence, in future works, scientists should give more consideration to membrane alteration by HPCD treatment, whose possible mechanisms we have introduced at length, in this review. To date, studies on the inactivation of spores and viruses by HPCD have been insufficient, especially on some food pathogens, such as Clostridium spores, which can cause spoilage, and foodborne illness. In addition, a further study of the mathematical modeling of the inactivation kinetics of various microorganisms should be conducted to provide data for industrial application.

More systematic and quantitative research on the influence of HPCD on food composition is needed, as this is essential for nutritive value, quality, and function, which directly 
influence consumer desire. Although Hibi et al. [100] concluded that no toxic materials exist in HPCD-treated bread, more work investigating the safety of HPCD-treated food needs to be done, because HPCD is a new pasteurization technology.

To satisfy consumers' increasing demands for food safety and quality, HPCD can provide a solution. Owing to the lower requirement for pressure (lower than $50 \mathrm{MPa}$ ) compared with HHP technology, HPCD has great advantages, such as low cost in equipment, larger scale production, and is much safer for operators. In addition, $\mathrm{CO}_{2}$ is cheap and is considered "green," in the context of food science, without toxicity. However, the process parameters (pressure, temperature, and treatment time) of HPCD for different foods need to be studied energetically. More efforts are needed to provide more convincing data for future, commercial-scale applications.

Acknowledgments We would like to thank Dr. Sachi Sri Kantha's suggestions and comments for improving this paper.

Availability of Data and Material Not applicable.

Code Availability Not applicable.

Author Contribution All authors contributed to the study conception and design. Data collection and analysis were performed by Tonghuan $\mathrm{Yu}$ and Liyuan Niu. The first draft of the manuscript was written by Tonghuan $\mathrm{Yu}$. The manuscript was critically revised by Hitoshi Iwahashi. All authors read and approved the final manuscript.

Funding Information We would like to thank the foundation support from the Toyo Suisan Foundation for Food Science and Research, Japan.

\section{Compliance with Ethical Standards}

Conflict of Interest The authors declare that they have no conflict of interest.

Ethics Approval Not applicable.

Consent to Participate We grant with full title guarantee all rights of copyrights and related rights in this manuscript, including whole text, figures, and supplemental tables.

Consent for Publication We agree with Food Engineering Reviews with all rights of the copyright and related publishing rights in this paper throughout the world in all languages once the manuscript was accepted.

\section{References}

1. Lee HS, Coates GA (2003) Effect of thermal pasteurization on valencia orange juice color and pigments. LWT Food Sci Technol 36(1):153-156

2. Cheng X, Imai T, Teeka J, Yamaguchi J, Hirose M, Higuchi T, Sekine M (2011) Inactivation of Escherichia Coli and Bacteriophage T4 by high levels of dissolved $\mathrm{CO}_{2}$. Appl Microbiol Biotechnol 90(4):1493-1500
3. Sapkal GN, Patil SM, Surwase US, Bhatbhage PK (2010) Supercritical fluid extraction. Int J Chem 8(2):729-743

4. Yamamoto K (2017) Food processing by high hydrostatic pressure. Biosci Biotechnol Biochem 81(4):672-679

5. Daryaei H, Yousef AE, Balasubramaniam VM (2016) High pressure processing of foods. In: Balasubramaniam VM, BarbosaCánovas G, HLM L (eds) Food Engineering Series. Springer, New York

6. Serment-Moreno V, Barbosa-Cánovas G, Torres J, Welti-Chanes J (2014) High-pressure processing: kinetic models for microbial and enzyme inactivation. Food Eng Rev 6(3):56-88

7. Georget E, Sevenich R, Reineke K, Mathys A, Heinz V, Callanan $M$ (2015) Inactivation of microorganisms by high isostatic pressure processing in complex matrices: a review. Innovative Food Sci Emerg Technol 27:1-14

8. Iwahashi H, Shimizu H, Odani M, Komatsu Y (2003) Piezophysiology of genome wide gene expression levels in the yeast Saccharomyces cerevisiae. Extremophile. 7:291-298

9. Tanaka Y, Higashi T, Rakwal R, Shibato J, Wakida S, Iwahashi H (2010) The role of proteasome in yeast Saccharomyces cerevisiae response to sublethal high-pressure treatment. High Pressure Res 30:519-523

10. Buzrul S (2015) Multi-pulsed high hydrostatic pressure treatment of foods. Foods 4(2):173-183

11. Alfaia A, Alfaia CM, Patarata L, Fernandes MJ, Fernandes MH, Elias M, Ribeiroa MH, Fraquezabet MJ (2015) Binomial effects of high isostatic pressure and time on the microbiological, sensory characteristics and lipid composition stability of vacuum packed dry fermented sausages "chouriço". Innovative Food Sci Emerg Technol 32:37-44

12. Hereu A, Dalgaard P, Garriga M, Aymerich T, Bover-Cid S (2012) Modeling the high pressure inactivation kinetics of listeria monocytogenes on RTE cooked meat products. Innovative Food Sci Emerg Technol 16:305-315

13. Campus M (2010) High pressure processing of meat, meat products and seafood. Food Eng Rev 2:256-273

14. Muntean MV, Marian O, Barbieru V, Catunescu GM, Ranta O, Drocas I, Terhes S (2016) High pressure processing in food industry-characteristics and applications. Agric and Agric Sci Procedia 10:377-383

15. García-Gimeno RM, Denisse G, Izquierdo P (2020) High hydrostatic pressure treatment of meat products. In: Food processing [working title]. https://doi.org/10.5772/intechopen.90858

16. Huang HW, Hsu CP, Wang CY (2020) Healthy expectations of high hydrostatic pressure treatment in food processing industry. $\mathrm{J}$ Food Drug Anal 28(1):1-13

17. Kyung KY, Takahashi J, Iwahashi H (2018) Optimization of polysaccharide extraction from medicinal mushrooms by combined enzyme-high hydrostatic pressure. J of the Japanese Society of Taste Technol 17(1):10-17

18. Takeda T, Shimada M, Ushida Y, Saito H, Iwamoto H, Okawa T (2015) Effects of sterilization process on the physicochemical and nutritional properties of liquid enteral formula. Food Sci Technol Res 21(4):573-581

19. John D, Ramaswamy HS (2018) Pulsed light technology to enhance food safety and quality: a mini-review. Curr Opin Food Sci 23:70-79

20. Nicorescu I, Nguyen B, Moreau-Ferret M, Agoulon A, Chevalier S, Orange N (2013) Pulsed light inactivation of Bacillus subtilis vegetative cells in suspensions and spices. Food Control 31:151157

21. Xu W, Wu C (2016) The impact of pulsed light on decontamination, quality, and bacterial attachment of fresh raspberries. Food Microbiol 57:135-143

22. Zenklusen MH, Coronel MB, Castro MA, Alzamora SM, Gonzalez HHL (2018) Inactivation of Aspergillus carbonarius 
and Aspergillus flavus in malting barley by pulsed light and impact on germination capacity and microstructure. Innov Food Sci Emerg Technol 45:161-168

23. Rock C, Guner S, Yang W, Gu L, Percival S, Salcido E (2015) Enhanced antioxidant capacity of fresh blueberries by pulsed light treatment. J Food Res 4:89-97

24. Panozzo A, Manzocco L, Lippe G, Nicoli MC (2016) Effect of pulsed light on structure and immunoreactivity of gluten. Food Chem 194:366-372

25. Zhao XY, Yang WD, Chung SY, Sims CA, Otwell SW, Rababah TM (2014) Reduction of IgE immunoreactivity of whole peanut (Arachis hypogaea L.) after pulsed light illumination. Food Bioprocess Technol 7:2637-2645

26. Abida J, Rayees B, Masoodi FA (2014) Pulsed light technology: a novel method for food preservation. Int Food Res J 21:839-848

27. Adarsh MK, Devaraju R (2017) Microwave energy and its application in food industry: a review. Asian J Dairy \& Food Res 36(1): $37-44$

28. Yoshikawa N (2020) Mechanism of microwave heating of matter. In: Horikoshi S, Serpone N (eds) RF power semiconductor generator application in heating and energy utilization. Springer, Singapore

29. Mendes-Oliveira G, Deering AJ, San Martin-Gonzalez MF, Campanella $\mathrm{OH}$ (2020) Microwave pasteurization of apple juice: modeling the inactivation of Escherichia coli O157:H7 and Salmonella Typhimurium at $80-90{ }^{\circ} \mathrm{C}$. Food Microbiol 87: 103382

30. Alirezalu K, Munekata PES, Parniakov O, Barba FJ, Witt J, Toepfl S, Wiktor A, Lorenzo JM (2019) Pulsed electric field and mild heating for milk processing: a review on recent advances. J Sci Food Agric 100:16-24. https://doi.org/10.1002/jsfa.9942

31. Poojary MM, Roohinejad S, KoubaaM BFJ, Passamonti P, Jambrak AR, Oey I, Greiner R (2017) In: Miklavcic D (ed) Impact of pulsed electric fields on enzymes. Handbook of electroporation. Springer, Cham, pp 2369-2389

32. Arcena MR, Leong SY, Hochberg M, Sack M, Mueller G, Sigler J, Silcock P, Kebede B, Oey I (2020) Evolution of volatile and phenolic compounds during bottle storage of merlot wines vinified using pulsed electric fields-treated grapes. Foods. 9(4):E443

33. Lin S, Liang R, Xue P, Zhang S, Liu Z, Dong X (2017) Antioxidant activity improvement of identified pine nut peptides by pulsed electric field (PEF) and the mechanism exploration. LWT Food Sci Technol 75:366-372

34. Morales-De La Pena M, Salvia-Trujillo L, Rojas-Grau A, MartínBelloso O (2017) Effects of high intensity pulsed electric fields or thermal treatments and refrigerated storage on antioxidant compounds of fruit juice-milk beverages. Part II: carotenoids. J Food Process Presrv 41(5):1-11

35. Gabric D, Barba F, Roohinejad S, Gharibzahedi SMT, Radojcin M, Putnik P, Kovacevic DB (2018) Pulsed electric fields as an alternative to thermal processing for preservation of nutritive and physicochemical properties of beverages: a review. J Food Process Eng 41:e12638

36. O'Donnell CP, Tiwari BK, Bourke P, Cullen PJ (2010) Effect of ultrasonic processing on food enzymes of industrial importance. Trends Food Sci Technol 21(7):358-367

37. Knorr D, Zenker M, Heinz V, Lee DU (2004) Applications and potential of ultrasonics in food processing. Trends Food Sci Technol 15(5):261-266

38. Tsukamoto I, Yim B, Stavarache CE, Furuta M, Hashiba K, Maeda Y (2004) Inactivation od Saccharomyces cerevisiae by ultrasonic irradition. Ultrason Sonochem 11(2):61-65

39. Gallo M, Ferrara L, Naviglio D (2018) Application of ultrasound in food science and technology: a perspective. Foods. 7(10):E164

40. Niakousari M, Gahruie HH, Razmjooei M, Roohinejad S, Greiner F (2018) Effects of innovative processing technologies on microbial targets based on food categories: comparing traditional and emerging technologies for food preservation. In: Innovative Technologies for Food Preservation. Academic Press, Cambridge, pp 133-185

41. Cassano A, Drioli E, Galaverna G, Marchell R, Silvestro GD, Cagnasso P (2003) Clarification and concentration of citrus and carrot juices by integrated membrane processes. J Food Eng 57(2): $153-163$

42. Corbo MR, Bevilacqua A, Campaniello D, D'Amato D, Speranza B, Sinigaglia M (2009) Prolonging microbial shelf life of foods through the use of natural compounds and non-thermal approaches - a review. Int J Food Sci Technol 44(2):223-241

43. Lacroix N, Fliss I, Makhlouf J (2005) Inactivation of pectin methylesterase and stabilization of opalescence in orange juice by dynamic high pressure. Food Res Int 38(5):569-576

44. Valley G, Rettger LF (1927) The influence of carbon dioxide on bacteria. J Bacteriol 14(2):101-137

45. Paniagua-Martínez I, Mulet A, García-Alvarado MA, Benedito J (2018) Inactivation of the microbiota and effect on the quality attributes of pineapple juice using a continuous flow ultrasoundassisted supercritical carbon dioxide system. Food Sci Technol Int 24(7):547-554

46. Chen YY, Temelli F, Gänzle MG (2017) Mechanisms of inactivation of dry Escherichia coli by high-pressure carbon dioxide. Appl Environ Microbiol 83(10):e00062-e00017

47. Marszalek K, Skąpska S, Woźniak L, Sokołowska B (2015) Application of supercritical carbon dioxide for the preservation of strawberry juice: microbial and physicochemical quality, enzymatic activity and the degradation kinetics of anthocyanins during storage. Innovative Food Sci Emerg Technol 32:101-109

48. Xu F, Feng X, Sui X, Lin H, Han Y (2017) Inactivation mechanism of Vibrio parahaemolyticus via supercritical carbon dioxide treatment. Food Res Int 100:282-288

49. Kobayashi F, Odake S (2020) Temperature-dependency on the inactivation of Saccharomyces pastorianus by low-pressure carbon dioxide microbubbles. J Food Sci Technol 57:588-594

50. Perez-Won M, Lemus-Mondaca R, Herrera-Lavados CE, Reyes J, Roco T, Palma-Acevedo A, Tabilo-Munizaga GP, Aubourg S (2020) Combined treatments of high hydrostatic pressure and $\mathrm{CO}_{2}$ in Coho Salmon (Oncorhynchus kisutch): effects on enzyme inactivation, physicochemical properties, and microbial shelf life. Foods. 9(3):273

51. González-Alonso V, Cappelletti M, Bertolini FM, Lomolino G, Zambon A, Spilimbergo S (2019) Microbial inactivation of raw chicken meat by supercritical carbon dioxide treatment alone and in combination with fresh culinary herbs. Poult Sci 99:536-545. https://doi.org/10.3382/ps/pez563

52. Fleury C, Savoire R, Harscoat-Schiavo C, Hadj-Sassi A, SubraPaternault P (2018) Optimization of supercritical $\mathrm{CO}_{2}$ process to pasteurize dietary supplement: influencing factors and $\mathrm{CO}_{2}$ transfer approach. The J of Supercritical Fluids 141:240-251

53. Rao L, Zhao L, Wang Y, Chen F, Hu X, Setlow P, Liao X (2019) Mechanism of inactivation of Bacillus subtilis spores by high pressure $\mathrm{CO}_{2}$ at high temperature. Food Microbiol 82:36-45

54. Spilimbergo S, Elvassore N, Bertucco A (2002) Microbial inactivation by high pressure. J Supercrit Fluids 22(1):55-63

55. Rao L, Bi XF, Zhao F, Wu JH, Hu XS, Liao XJ (2015) Effect of high-pressure $\mathrm{CO}_{2}$ processing on bacterial spores. Crit Rev Food Sci Nutr 56(11): 1808-1825

56. Vo HT, Imaia T, Ho TT, Sekine M, Kanno A, Higuchi T, Yamamoto K, Yamamoto H (2014) Inactivation effect of pressurized carbon dioxide on Bacteriophage $Q \beta$ and $\Phi X 174$ as a novel disinfectant for water treatment. J Environ Sci 26(6):1301-1306

57. Vo HT, Imai T, Yamamoto H, Van LET, Higuchi T, Kanno A, Yamamoto K, Sekine M (2013) Disinfection using pressurized 
carbon dioxide microbubbles to inactivate Escherichia coli, bacteriophage MS2 and T4. J Water Environ Tech 11(6):467-505

58. Chen JL, Zhang J, Song LJ, Jiang Y, Wu JH, Hu XS (2010) Changes in microorganism, enzyme, aroma of hami melon (Cucumis melo L.) juice treated with dense phase carbon dioxide and stored at $4^{\circ} \mathrm{C}$. Innovative Food Sci Emerg Technol 11(4):623629

59. Vo HT, Imai T, Ho TT, Dang TL, Hoang SA (2015) Potential application of high pressure carbon dioxide in treated wastewater and water disinfection: recent overview and further trends. J Environ Sci (China) 36:38-47

60. Garcia-Gonzalez L, Geeraed AH, Spilimbergo S, Elst K, Van Ginneken L, Debevere J, Van Impe JF, Devlieghere F (2007) High pressure carbon dioxide inactivation of microorganisms in foods: the past, the present and the future. Int J Food Microbiol 117(1):1-28

61. Tsuji M, Sato Y, Komiyama Y (2005) Inactivation of microorganisms and enzymes in juices by supercritical carbon dioxide method with continous flow system. Nippon Shokuhin Kagaku Kogaku Kaishi 52(11):528-531

62. Checinska A, Fruth IA, Green TL, Crawford RL, Paszczynski AJ (2011) Sterilization of biological pathogens using supercritical fluid carbon dioxide containing water and hydrogen peroxide. J Microbiol Methods 87(1):70-75

63. Hemmer JD, Drews MJ, LaBerge M, Matthews MA (2006) Sterilization of bacterial spores by using supercritical carbon dioxide and hydrogen peroxide. J Biomed Mater Res B Appl Biomater 80(2):511-518

64. White A, Burns D, Christensen TW (2006) Effective terminal sterilization using supercritical carbon dioxide. J Biotechnol 123(4):504-515

65. Briones LS, Reyes JE, Tabilo-Munizaga GE, Pérez-Won MO (2010) Microbial shelf-life extension of chilled Coho salmon (Oncorhynchus kisutch) and abalone (Haliotis rufescens) by high hydrostatic pressure treatment. Food Control 21:1530-1535

66. Liao HM, Zhang FS, Liao XJ, Hu XS, Chen Y, Deng L (2010) Analysis of Escherichia Coli cell damage induced by HPCD using microscopies and fluorescent staining. Int J Food Microbiol 144(1):169-176

67. Niu LY, Nomura K, Iwahashi H, Matsuoka H, Kawachi S, Suzuki Y, Tamura K (2017a) Petit -high pressure carbon dioxide stress increases synthesis of S -adenosylmethionine and phosphatidylcholine in yeast Saccharomyces Cerevisiae. Biophys Chem 231: 79-86

68. Tamburini S, Anesi A, Ferrentino G, Spilimbergo S, Guella G, Jousson O (2014) Supercritical $\mathrm{CO}_{2}$ induces marked changes in membrane phospholipids composition in Escherichia Coli K12. J Membr Biol 247(6):469-477

69. Takahashi U, Hamada K, Iwahashi H (2019) Critical damage to the cellular organelles of Saccharomyces cerevisiae under sublethal conditions upon high pressure carbon dioxide treatment. High Pressure Res 39(2):273-279

70. Xie J, Bogdanov M, Heacock P, Dowhan W (2006) Phosphatidylethanolamine and monoglucosyldiacylglycerol are interchangeable in supporting topogenesis and function of the polytopic membrane protein lactose permease. J Biol Chem 281(28):19172-19178

71. Ma Y, Poole K, Goyette J, Gaus K (2017) Introducing membrane charge and membrane potential to T cell signaling. Front Immunol $8: 1513$

72. Parks LC, Rigney D, Daneo-Moore L, Higgins ML (1982) Membrane-DNA attachment sites in Streptococcus faecalis cells grown at different rates. J Bacteriol 152(1):191-200

73. Monhemi H, Dolatabadi S (2020) Molecular dynamics simulation of high-pressure $\mathrm{CO}_{2}$ pasteurization reveals the interfacial denaturation of proteins at $\mathrm{CO}_{2}$ /water interface. J CO2 Util 35:256-264
74. Niu LY, Nomura K, Iwahashi H, Matsuoka H, Kawachi S, Suzuki Y, Tamura K (2017b) Urea cycle is enhanced by petit-high pressure carbon dioxide stress in Yeast Saccharomyces Cerevisiae. High Pressure Res 37(1):70-77

75. Setlow P (2006) Spores of Bacillus subtilis: their resistance to and killing by radiation, heat and chemicals. J Appl Microbiol 101(3): 514-525

76. Leggett MJ, McDonnell G, Denyer SP, Setlow P, Maillard JY (2012) Bacterial spore structures and their protective role in biocide resistance. J Appl Microbiol 113(3):485-498

77. Rao L, Zhao F, Wang YT, Chen F, Hu XS, Liao XJ (2016) Investigating the inactivation mechanism of Bacillus Subtilis spores by high pressure $\mathrm{CO}_{2}$. Front Microbiol 7:1411

78. Rao L, Wang Y, Chen F, Hu X, Liao X, Zhao L (2020) High pressure $\mathrm{CO}_{2}$ reduces the wet heat resistance of Bacillus subtilis spores by perturbing the inner membrane. Innov Food Sci Emerg Technol 60:102291

79. Murtaza A, Iqbal A, Marszałek K, Iqbal MA, Ali SW, Xu X, Pan S, Hu W (2020) Enzymatic, phyto-, and physicochemical evaluation of apple juice under high-pressure carbon dioxide and thermal processing. Foods. 9(2):243

80. Benito-Román Ó, Sanz MT, Melgosa R, de Paz E, Escudero I, Beltrán S (2019) Studies of polyphenol oxidase inactivation by means of high pressure carbon dioxide (HPCD). The J of Supercrit Fluids 147:310-321

81. Ceni G, Fernandes Silva M, Valério C Jr, Cansian RL, Oliveira JV, Dalla Rosa C, Mazutti MA (2016) Continuous inactivation of alkaline phosphatase and Escherichia coli in milk using compressed carbon dioxide as inactivating agent. J CO2 Util 13:24-28

82. IftikharT WME, Rizvi SSH (2014) Enhanced inactivation of pectin methyl esterase in orange juice using modified supercritical carbon dioxide treatment. Int J Food Sci Technol 49(3):804-810

83. Kobayashi F, Odake S, Kobayashi K, Sakurai H (2016) Effect of pressure on the inactivation of enzymes and hiochi bacteria in unpasteurized sake by low-pressure carbon dioxide microbubbles. J Food Eng 171:52-56

84. Liao X, Zhang Y, Bei J, Hu X, Wu J (2009) Alterations of molecular properties of lipoxygenase induced by dense phase carbon dioxide. Innov Food Sci Emerg Technol 10(1):47-53

85. Manzocco L, Plazzotta S, Spilimbergo S, Nicoli MC (2017) Impact of high-pressure carbon dioxide on polyphenoloxidase activity and stability of fresh apple juice. LWT Food Sci Technol 85:363-371

86. Marszałek K, Doesburg P, Starzonek S, Szczepańska J, Woźniak Ł, Lorenzo JM, Skąpska S, Rzoska S, Barba FJ (2019) Comparative effect of supercritical carbon dioxide and high pressure processing on structural changes and activity loss of oxidoreductive enzymes. J CO2 Util 29:46-56

87. Benito-Román Ó, Sanz MT, Illera AE, Melgosa R, Benito JM, Beltrán S (2018) Pectin methylesterase inactivation by high pressure carbon dioxide (HPCD). The J of Supercrit Fluids 145:111121

88. Briongos H, Illera AE, Sanz MT, Melgosa R, Beltrán S, Solaesa AG (2016) Effect of high pressure carbon dioxide processing on pectin methylesterase activity and other orange juice properties. LWT Food Sci Technol 74:411-419

89. Liao H, Zhong K, Hu X, Liao X (2019) Effect of high pressure carbon dioxide on alkaline phosphatase activity and quality characteristics of raw bovine milk. Innovative Food Sci Emerg Technol 52:457-462

90. Silva EK, Arruda HS, Eberlin MN, Pastore GM, Meireles MAA (2019) Effects of supercritical carbon dioxide and thermal treatment on the inulin chemical stability and functional properties of prebiotic-enriched apple juice. Food Res Int 125:108561

91. Marszałek K, Krzyżanowska J, Woźniak Ł, Skąpska S (2017) Kinetic modelling of polyphenol oxidase, peroxidase, pectin 
esterase, polygalacturonase, degradation of the main pigments and polyphenols in beetroot juice during high pressure carbon dioxide treatment. LWT Food Sci Technol 85:412-417

92. Gasperi F, Aprea E, Biasioli F, Carlin S, Endrizzi I, Pirretti G, Spilimbergo $\mathrm{S}$ (2009) Effects of supercritical $\mathrm{CO}_{2}$ and $\mathrm{N}_{2} \mathrm{O}$ pasteurisation on the quality of fresh apple juice. Food Chem 115(1):129-136

93. Niu LY, Hu XS, Wu JH, Liao XJ, Chen F, Zhao GH, Wang ZF (2010) Effect of dense phase carbon dioxide process of physicochemical properties and flavor compounds of orange juice. J Food Process Preserv 34:530-548

94. Gui FQ, Wu JH, Chen F, Liao XJ, Hu XS, Zhang ZH, Wang ZF (2006) Change of polyphenol oxidase activtiy, color, and browning degree during storage of cloudy apple juice treated by supercritical carbon dioxide. Eur Food Res Technol 223(3):427-432

95. Park SJ, Lee JI, Park J (2002) Effects of a combined process of high-pressure carbon dioxide and high hydrostatic pressure on the quality of carrot juice. J Food Sci 67(5):1827-1834

96. Zhou LY, Zhang Y, Leng XJ, Liao XJ, Hu XS (2010) Acceleration of precipitation formation in peach juice induced by high-pressure carbon dioxide. J Agric Food Chem 58(17): 9605-9610

97. Bi XF, Wu JH, Zhang Y, Xu ZH, Liao XJ (2011) High pressure carbon dioxide treatment for fresh-cut carrot slices. Innovative Food Sci Emerg Technol 12(3):298-304

98. Noomhorm A, Sirisoontaralak P, Uraichuen J, Ahmad I (2009) Effects of pressurized carbon dioxide on controlling Sitophilus Zeamais (Coleoptera: Curculionidae) and the quality of milled rice. J Stored Prod Res 45(3):201-205

99. Valverde MT, Marin-Iniesta F, Calvo L (2010) Inactivation of Saccharomyces cerevisiae in conference pear with high pressure carbon dioxide and effects on pea qulity. J Food Eng 98(4):421428

100. Hibi A, Ohno T, Moriyama A, Himaki T, Takahashi J, Iwahashi H (2019) Evaluation of the effect of high pressure carbon dioxidepasteurized food on animal health. High Pressure Res 39(2):357366

Publisher's Note Springer Nature remains neutral with regard to jurisdictional claims in published maps and institutional affiliations. 